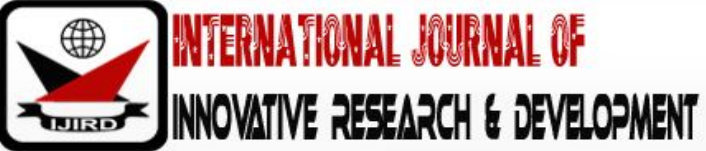

ISSN 2278 - 0211 (Online)

\section{Organisational Support, Teachers' Job Satisfaction and Commitment in Colleges of Education in Ghana: A Qualitative Study}

\author{
Laud Teye Nartey \\ Lecturer, Department of Science, OLA College of Education, Central Region, Cape Coast, Ghana
}

\begin{abstract}
:
The study focused on examining the dynamism of the relationship between organisational support, teachers' job satisfaction, and commitment in the colleges of education in Ghana Thus, the exploratory research design was adopted due to the nature of the study. The study also used the qualitative approach. Qualitative research is exploratory in nature, and its methodologies allow for a more productive and more in-depth understanding of a process or a phenomenon. The population this study focused on was teachers of colleges of education in Ghana. Interviews were conducted to gather data. The study inferred that teachers have a low level of commitment to the institution which is as a result of poor working conditions.
\end{abstract}

Keywords:Colleges of education, job satisfaction, organisational support, teacher commitment, qualitative study

\section{Introduction}

Employees are perceived as one of the most vital resources for most institutions, especially service-based institutions like colleges of education, because of the benefits of affording efficacious performances (see Herzberg 2003). Attaining service quality and excellence and satisfying and maintaining loyal clients is contingent on the attitudes, performance and behaviour of employees (Thomson \& Phua 2012). As pointed out by Garg \& Rastongi (2006), satisfied employees lead to organizational success. Organisational support is one of the most criticalorganizational concepts that keep employees in the organisation since organizational support is known as a critical factor in increasing job satisfaction and the commitment of employees. On the other hand, organisational commitment and job satisfaction are equally crucial to customer satisfaction (Robbins \& Judge, 2009).

Several studies have discovered that job satisfaction and organisational commitment are related, however, as inferred by Porter et al., (1974), they have distinguishable attitudes. Nevertheless, job satisfaction is considered as an antecedent of organizational commitment (see Baotham et al. 2010; Yang, 2010). The primary reason for this appears to be the fact that a more considerable amount of time would be required for employees to determine their level of commitment to the organisation than would be the case with their level of job satisfaction since the degree of one's job satisfaction is mostly associated with specific and tangible aspects of the work environment and may represent a more rapidly formed affective response than commitment (Porter et al., 1974).

Considering the relationships between the three concepts, organizational support, job satisfaction and organizational commitment, it is appreciated that job satisfaction is not only the consequence of organizational support but also an antecedent of organizational commitment. Some studies have proposed fundamental models of organisational commitment in which the effects of various antecedent variables like supportive culture, leadership style, pay, promotional probabilities, supervisory support, workload, role conflict and ambiguity, autonomy, and job characteristics on commitment are mediated through their effects on job satisfaction (Wright \& Cropanzano 2000). The principal objective of this study is to qualitatively determine the impact of organisational support on teachers' commitment, examine the extent to which job satisfaction affects the level of commitment as well as determine the relationship between organisational support and teacher commitment in colleges of education in Ghana.

\section{Literature review}

\subsection{Organisational Support}

Organisational support is described by Thomson \& Phua (2012) as a common belief in which workers perceive that their organization appreciates their contributions and cares about their well-being. Organisational support stems from the organizational support theory by Eisenberger et al. (1986). It explains the relationship between employers and workers based on social exchange theory, and how workers perceive support contingent on how they personify the organization. 
According to the theory, employees view the organization as having human-like characteristics and take its favourable treatment or unfavourable treatment as an indication that the organizationfavours or disfavours them as an individual. Organisational support is the beliefs of employees (Krishan \& Mary, 2012) regarding the extent to which the organization meets their socio-emotional needs, and how the organization responds to increased efforts at work.

Some factors like organizational rewards, job conditions, and perceived fairness are believed to influence how employees perceive organizational support, (Mahdi et al., 2012). Organizational rewards and job conditions according to Rhoades \& Eisenberger, (2001) incorporate methods in which employees are recognized for their contributions and the working environment itself. This includes rewards and conditions like recognition, pay, promotions, job security, job autonomy, training and development experiences, and work-family policies (Rhoades \& Eisenberger, 2001). Employees estimate the amount of assistance and equipment provided to them by the organization to help them complete projects, as well as being given training and development in areas that are of interest to them (Gomes 2009).

\subsubsection{Organizational Support Theory}

Organizational support theory embraces the work of early theories and forms the theoretical framework by which perceived organizational support is studied. (Eisenberger et al., 1997; Eisenberger \& Stinglhamber, 2011). Organizational support theory assumes that employees develop a general perception of the degree to which their institution appreciates their contributions and cares about their well-being (Eisenberger et al. 2014). In as much as individuals attempt to gauge another person's level of commitment to a friendship or romantic relationship, employees also attempt to determine the organization's willingness to reward their efforts and meet their needs by making inferences about the organization's level of support for them (Eisenberger et al., 1986).

The theory postulates that employees develop some degree of organisational support based on how the organization treatments of them. When an organization treats its employees well or poorly, they make ascriptions regarding why the organization treated them in that particular way. Employees who perceive that the organization treats them well because of sincere regard for their welfare are likely to develop high organizational support perceptions. Organizational support theory descends in part from social exchange theory, which explains the exchange of goods or services between people (Blau, 1964). Individuals are motivated to enter and develop relationships with others when the relationship promises something valuable in return.

High-quality, mutually beneficial relationships evolve over time only when parties abide by rules of exchange (Gebremichael \& Rao 2013; Azeem 2010). Although organizational support theory draws heavily from social exchange theory, it also underscores self-enhancement processes as an essential component of the employee-organization relationship. Self-development helps maintain the social identities, which denote the characteristics of self-image that originate from the social categories or groups to which individuals perceive they belong (Tajfel \& Turner 1985). Consequently, when employees feel supported by the organization, they develop identification with the organization in which their organizational membership becomes a meaningful, positive part of their personal identities.

\subsection{Organizational Commitment}

Allen \& Meyer (1991) describe organisational commitment as a psychological state that binds the individual to the organization. The concept of organizational commitment has been researched immensely, as there is much curiosity to comprehend the nature of employee dedication in an organizational setting (Eisenberger et al. 2002). Mowday et al. (1993), explained it as the relative strength of an individual's identification with, and involvement in, an organization. This definition has nonetheless been criticized for presenting the consequences of commitment rather than its motives. Meyer \& Allen (1991) presented a model consisting of three approaches to commitment. These comprise affective, continuance and normative commitment. This description has received the most support.

According to Allen \& Meyer (1991), affective and continuance commitments are empirically distinguishable; however, affective and normative commitment appears to be connected with each other. Meyer \& Allen (1997), define affective commitment as an emotional attachment to an organization; a firmbelief in, and assent of the organization's aims and values which results in a willingness to exert optimal effort to achieve the organization's goals. However, Aydogdu \& Asikgil (2011) advanced the description of affective commitment by asserting it is as an attachment grounded on a sharing of values with other members of the organization. They further defined continuance commitment as being premised on the perception that an employee has no realistic choice or viable alternatives other than to remain with the organization. Allen \& Meyer (1990) explained normative commitment to be an employee's feeling of obligation to continue working for an organization.

It has been suggested that all three categories of commitment are components of attitudinal commitment. Employees can experience these psychological states varyingly (Allen \& Meyer 1991). Besides, Allen \& Meyer note that an employee's commitment can be based on all three of the components. Each of these three components has different antecedents (Allen \& Meyer 1990). For affectivecommitment, the strongest antecedent is work experiences that fulfil employees' psychological needs to feel comfortable in their role and the organization as well as competent in the job. Continuance commitment, on the other hand, has to do with the level of investments employees make. According to Akanbi \& Itiola (2013), people's organizational commitment can change accordingly when a change occurs to a particular aspect of the job or the organization. Swailes (2002) specified that the labour market had become more dynamic since the 1970s when the concept of organizational commitment became a relevant issue of research. 


\subsection{Job Satisfaction}

In public administration and human resource management, the concept of job satisfaction is essential; hence, it is widespread in management literature. Job satisfaction is viewed as a multidimensional concept, and thus no single definition or universal definition could be assigned to it. However, most of the definitions given by authors seem to follow the same logic. These authors have defined job satisfaction as feelings or better yet the constellation of attitudes that employees have about their jobs and other related aspects of their jobs. According to these authors job satisfaction refers to the degree to which employees like (satisfied) or dislike (dissatisfied) their jobs (see Mohammed \& Eleswed 2013; Haorei 2012; Malik et al. 2010; Mudor and Tooksoon, 2011). This simple definition of job satisfaction means that teachers' job satisfaction within the context of this study is the emotional state of teachers that arise from how they appraise their job and experiences.

As mentioned above, as a result of its connection with vitalorganizational phenomena, such as turnover, absenteeism and organizational effectiveness, job satisfaction has been an issue of concern for many in the past (see Babin \& Boles 1996; lark, 1997; Castillo \& Cano 2004; Gazioglu \& Tanselb 2006). According to Kanter (1993), an employee being content with their existing job's contents does not ensure the equal level of satisfaction at the same time for their potential professional advancement or internal mobility in the company. On the contrary, various reasons led to job dissatisfaction. Numerous investigations have confirmed that when workers lack a precise description of the actions which are necessary to fulfil a specific role, their levels of job satisfaction are likely to be negatively affected (Samavi 2011; Klassen \& Chiu 2010; Edmonson, 2006).

\subsection{Colleges of Education in Ghana}

The institutions responsible for the training of teachers in Ghana was formerly called Teacher Training Colleges. They are now known as Colleges of Education. In the early 2000s, following a comprehensive review of the educational system in Ghana, the Government published a White Paper and declared all Teacher Training Colleges be upgraded into diploma-awarding institutions and be affiliated to the education-oriented universities (Government of Ghana, 2004). In this regard, 38 Teacher Training Colleges operating at a level equivalent to level 4 of the International System of Classification of Education (ISCED 4) were re-designated as Colleges of Education (COE) to offer tertiary education in 2008.

This came about because they now run Diploma in Basic Education programmes and successful graduates after the three academic year period of training successful graduates are awarded Diploma Certificates in Basic Education which has replaced the former Certificate ' $\mathrm{A}$ ' Three- Year Post Secondary Certificate (Government of Ghana 2012). The Colleges of Education have the sole responsibility of training professional teachers for Ghana. These teachers are responsible for teaching in Basic schools that comprise Primary and Junior High schools. (Opare 2008).

\section{Methodology}

This study employed the qualitative approach. Qualitative research (Creswell 2014) is exploratory in nature, and its methodologies allow for a more productive and more in-depth understanding of a process or a phenomenon. Again, as inferred by Willig (2013) the qualitative approach to research is in-depth using a range of techniques, which aims to understand why people think, feel, react and behave in the way that they do. However, samples tend to be small (Tracey 2013) as the aim is to generate concepts, strategies, or, an appreciation of processes that govern groups or institutions. The benefit of qualitative approaches according to Silverman (2009) and Tashakkori \& Teddlie (2010) is that the researcher does not start with a hypothesis that needs to be proved as this can make the study very rigid. Instead, it is an open-ended approach that can be adapted and changed while the research is ongoing, which enhances the quality of the data and insights generated.

Furthermore, the qualitative approach according to Merriam (2009) aims to generate in-depth accounts from individuals and groups by talking with them, watching their behaviour, analysing their artefacts, and bearing in mind the different contexts in which they are based. The target study population was the teachers of colleges of education in Ghana. Consequently, the purposive sampling technique was used to select Ola college of education. According to Palinkas et al. (2015), purposive sampling techniques are widely used in qualitative research for the identification and selection of information-rich cases for the most effective use of limited resources. Thus, purposive sampling technique was used to select 59 samples and interviewed.

\section{Results}

As indicated in the methodology, teaching staff of the college of education who were knowledgeable or experienced and who were available and willing to participate, and had the ability to communicate experiences as well as opinions in an articulate, expressive, and reflective manner were selected and interviewed on a variety of issues related to the objectives of the study the responses are thus organised according to the objectives of the study.

\subsection{Impact of Organisational Support on Teachers' Commitment}

Respondents were asked to give accounts on what they perceive to be the impact of the support the institution gives them and the extent to which they can connect with their commitment to the institution. Careful analysis of the responses gives the impression that respondents recognise that the institution's support they receive is very vital to their continued commitment to the institution. They believe that with the institution supporting their work that is when they realise that the institution cares about their well-being and hence they tend to reciprocate that with a higher form of emotional attachment to assisting the school to achieve its objectives. Selected comments have been outlined below; 
"...it is very true, and I think that when the institution earns the reputation of an institution that addresses employees needs and concerns then obviously the workers too will kill themselves and work for you. It works in the opposite direction too because if youdo not support them then they will not also help the company and that is even more dangerous of a thing to do...."

Another worthy comment also maintained that;

"workers definitely need the utmost support of the institution to deliver. I think the rule of thumb is that if you employ me,you have to perform your part by making sure that I have no need or any limitation on my part when it comes to doing my job.... however, what do we see in Ghana you would understand that teachers are the least cared for among all public servants and yet so much is expected of us..."

Another respondent pointed out that when it comes to commitment much needs to be done by the government through the ministry as there is no need understating the importance of organisational support in enforcing the commitment of teachers. That notwithstanding, most of the teachers who had the opportunity noted, in summary, the following;

"...we teachers demand a high level of institutional and government support when it comes to our work to compensate for our efforts and loyalty to stay in the profession because if things do notchange,we would think twice...".

From the responses, it can, therefore, be concluded that the respondents interviewed recognize the fact that worker commitment or employee attachment to their respective organization signals that workers contributions, as well as experiences, are dependent to a large extent on the extent of organizational support they receive. This falls in line with literature as the theory of social exchange maintains that organizational support has become a contemporary influence in determining the value and true meaning of exchange relationships between employees and their employers. Another relevance of the organizational support is that it clearly sends a message to employers of the expected behavioural attitudes of their employees.

\subsection{The Extent to Which Job Satisfaction Affects Teachers' Level of Commitment}

There is an interaction between employees' perception, insight, observation and views about the nature of jobs as well as their working environment and that employees' satisfaction affects the level of commitment to their respective organizations. Proponents have defined it as an emotional and sentimental belonging of an individual to the course of an organization or institution. From this background, the respondents' views were sought in the bid to find out the extent to which their job satisfaction affects their level of commitment and sense of belonging to the institution.

The responses reflect a rather exciting position adopted by the respondents. Majority of the responses suggests that the respondents are not satisfied with the current conditions they are afforded on the job. They believe that their working conditions are nothing to write home about and they assert that given the opening of any opportunity they will leave the service. Per their responses, it could be assumed that there is instead a low sense of belonging to the institution as are unsatisfied with their current working conditions. Selected responses have been given below;

"But you have to know by now that the teaching profession in Ghana is not good... we work and work but nothing to show for. You are marking scripts, planning for lessons, attending classes, dealing with students and yet after all these my pay cannot even take me beyond one month.... for me this is just a stepping stone!!!!”

"There are a lot of problems in the system mostly we have so many issues as teachers in this college. The kind of system is so politicised that you have little breath of free conscience to do anything meaningful....it is when there is utmost satisfaction derived from doing something you consider passionate that you stay committed to, but here it is not like that most of us wants to leave here for other schools..."

"...satisfied with this work? What kind of question is that? How can we be satisfied? We have really relegated been to the background it is this government that we can see is trying to do something, but overall, I can tell you much needs to be done because our commitment level is really down...I have friends tutoring in other colleges of education who tell me some of their colleagues are leaving for China and Japan. Why?"

From the responses, it can be concluded that most respondents recognize the current state of their working conditions and as such describes it as inadequate. It can be said they have a low level of commitment to the institution which is as a result of poor working conditions.

\subsection{The Relationship between Organisational Support and Teacher Commitment}

The respondents were further inquired to give their opinions regarding what they think of the relationship between organizational support and teacher commitment. They asserted that these three elements are firmly related as in one way or the other they all lead to one thing. It is somewhat inspiring to note that the respondents instead chose to rank the three elements of which the majority believed that organizational support remains the foundation for the other two factors. Beyond organizational support comes commitment which according to the respondents leads to job satisfaction. Selected comments have been elaborated below;

"I think the three things are very related... there cannot be job commitment when the support from

the institution is absent or unavailable. So, I think institutional support comes first which will bring 
out the commitment in people by making them comfortable and easy to do their respective work and given this enabling environment the employees get satisfied on the job. That is how it happens...."

Another maintained that;

"They are interrelated because when you think through it critically,you would see that mostly workers are not satisfied with the works they do because they normally don't get the support as they ought to receive and that makes them less committed to the organization. I think it is a cyclical thing other than that Ido not see how they interplay together...."

Interesting one respondent noted;

"Let me use myself as an example as I sit here talking to you I have the intention of abandoning post from this college because we don't get the support its all stress and some of us are of the view that the colleges of education have to be upgraded to the university status so that all those donkey jobs of having to supervise a 24-year-old to learn will be taken away.Ido not understand this... why should I lose sleep over a 24, 25-year-old who has decided not to learn? No so we think it's about time if this upgrade is not done and an opportunity presents itself we would leave that is that...."

Analysis of the responses gives course to conclude that the respondents have due understanding and appreciation of the interplay between organizational support, commitment and job satisfaction. Many believe that there is more work to be done as there is an increasing level of discontentment in the education sector. Teachers are the knowledge bearers of the country and should they lose interest and their sense of commitment and passion to the sector nothing holds in stock for the future generation. From the results, it can be concluded that teachers are not satisfied with their jobs because there is the lack of institutional support from their respective colleges of education which is gradually leading to the state where teachers have no form of commitment, belonging or attachment to the institution.

\section{Conclusion}

It can be concluded from the interviews that the respondents recognize the fact that worker commitment or employee attachment to their respective organization signals that workers contributions as well as experiences are reliant on to a large extent on the degree of organizational support they receive. Furthermore, the respondents recognize the current state of their working conditions and as such describes it as inadequate. Also, it can be inferred that they have a low level of commitment to the institution which is as a result of poor working conditions. Furthermore, the respondents have an understanding and appreciation of the interplay between organizational support, commitment and job satisfaction.

Many of the respondents believe that there is more work to be done as there is an increasing level of discontentment in the education sector. Teachers are the knowledge bearers of the country and should they lose interest and their sense of commitment and passion to the sector nothing holds in stock for the future generation. From the results, it can be concluded that teachers are not satisfied with their jobs because there is the lack of institutional support from their colleges which is gradually leading to the state where teachers have no form of commitment, sense of belonging or attachment to the institution.

\section{References}

i. Akanbi, P. A., \&Itiola, K. A. (2013). Exploring the relationship between job satisfaction and organizational commitment among health workers in Ekiti State, Nigeria. Journal of Business and Management Sciences, 1, 18-22

ii. Aydogdu, S., \&Asikgil, B. (2011). An empirical study of the relationship among job satisfaction, organizational commitment and turnover intent. International Review of Management and Marketing, 1, 43-5.

iii. Azeem, S. M. (2010).Job satisfaction and organizational commitment among employees in the sultanate of Oman. Psychology, 1, 295-299.

iv. Babin, J. B., \& Boles, J. S. (1996). The Effects of Perceived Co-Worker Involvement and Supervisor Support on Service Provider Role Stress, Performance and job Satisfaction. Journal of Retailing, 72(1), 57-75

v. Baotham, S., Hongkhuntod, W. \& Rattanajun, S. (2010). The effects of job satisfaction and organizational commitment on voluntary turnover intentions of Thai Employees in the new university. Review of Business Research, 10(1), pp. 73-82.

vi. Blau, P. M. (1964). Exchange and power in social life. New York: John Wiley.

vii. Castillo, J. X., \& Cano, J. (2004). Factors Explaining Job Satisfaction Among Faculty. Journal of Agricultural Education, 45(3), 65-74.

viii. Creswell, J. W. (2014). Research Design: Qualitative, Quantitative and Mixed Methods Approaches (4th ed.). Thousand Oaks, CA: Sage.

ix. Edmonson, V.C., (2006). Commentary, organizational surveys: a system for employee voice. Journal of Applied Communication Research. 34(4), 307-310.

x. Eisenberger, R. Huntington R, Hutchison. S, \& Sowa, D. (1986). Perceived organizational support. Journal of Management Reviews, 71(3): 500-507.

xi. Eisenberger, R., \& Stinglhamber, F. (2011). Perceived organizational support: Fostering enthusiastic and productive employees. Washington, DC: American Psychological Association.

xii. Eisenberger, R., Cummings, J., Aemeli, S., \& Lynch, P. (1997). Perceived organizational support, discretionary treatment, and job satisfaction. Journal of Applied Psychology, 82(5), 812-820. 
xiii. Eisenberger, R., Shoss, M. K., Karagonlar, G., Gonzalez-Morales, M. G., Wickham, R., \& Buffardi, L. C. (2014). The supervisor POS-LMX-subordinate POS chain: Moderation by reciprocation wariness and supervisor's organizational embodiment. Journal of Organizational Behavior, 35: 635-656.

xiv. Garg, P. \& Rastongi, R. (2006). New model of job design motivation employees Performance. Journal of Management Development.

xv. Gazioglu, S., \& Tanselb, A. (2006). Job Satisfaction in Britain: Individual and Job-Related Factors. Applied Economics, 38(10), 1163-1171.

xvi. Gebremichael, H., \& Rao, B. P. (2013). Job satisfaction and organizational commitment between academic staff and supporting staff (Volaita Sodo University-Ethiopia as a Case). Far East Journal of Psychology and Business, 11, 1132.

xvii. Gomes, D. R. (2009). Organizational change and job satisfaction: The mediating role of organizational commitment. Exedra, 1, 177-195.

xviii. Government of Ghana (2004). White paper on the report of the education reform review committee. Accra: Ministry of Education, Youth and Sports.

xix. Government of Ghana (2012). Colleges of education act, 2012, Act 847. Accra: Government of Ghana.

xx. Haorei, A. (2012). Human resource practices and employee retention, evidences from banking sector of Pakistan. Journal of business and management research, 7, 186-188.

xxi. Herzberg, F. (2003). One more time: how do you motivate employee? Harvard Business Review, 81, 56-96.

xxii. Kanter, R. M. (1993). Men and women of the corporation (2nd edn). New York: Basic Books.

xxiii. Klassen, R. M., \& Chiu, M. M. (2010). Effects on Teachers' Self-Efficacy and Job Satisfaction: Teacher Gender, Years of Experience, and Job Stress. Journal of Educational Psychology, 102(3), 741-756.

xxiv. Lark, A. E. (1997). Job satisfaction and gender: Why are women so happy at work? Labour economics, 4(4), 341372.

xxv. Locke, E. A., (1976) The Nature and Cause of Job Satisfaction, In M. Dunnette (Ed.), Handbook of Industrial and Organizational Psychology (Rand McNally, Chicago.

xxvi. Mahdi, A. F., Zin, M. Z. M., Nor, M. R. M., Sakat, A. A., \& Naim, A. S. A. (2012). The relationship between job satisfaction and turnover intention. American Journal of Applied Sciences, 9, 1518-1526.

xxvii. Malik, M. E., Nawab, S., Naeem, B., \& Danish, R. Q. (2010).Job satisfaction and organizational commitment of university teachers in public sector of Pakistan. International Journal of Business and Management, 5, 17-28.

xxviii. Merriam, S. B. (2009). Qualitative Research: A Guide to Design and Implementation. San Francisco, CA: John Wiley $\&$ Sons.

xxix. Meyer, J. P., \& Allen, N. J. (1991). A three-component conceptualization of organizational commitment. Human Resource Management Review, 1(1), 61- 89.

xxx. Mohammed, F., \& Eleswed, M. (2013). Job satisfaction and organizational commitment: A correlational study in Bahrain. International Journal of Business, Humanities and Technology, 3, 43-53.

xxxi. Mowday, R., \& Sutton, R. (1993). Organisational behaviour: Linking individuals and groups to organisational context. Annual Review of Psychology, 2, 195-229.

xxxii. Mudor, H., \& Tooksoon, P. (2011). Conceptual framework on the relationship between human resource management practices, job satisfaction, and turnover. Journal of Economics and Behavioral Studies, 2, 41-49.

xxxiii. Opare, J.A. (2008). The transition of Ghanaian training colleges to tertiary level: Prospects, challenges and the way forward. In PRINCOF, Developments in Basic Teacher Education in Ghana (pp. 155-158). Kumasi: Greenland's Concept.

xxxiv. Palinkas, L.A., Horwitz, S.M., Green, C.A. Wisdom, J. P. Duan, N. \& Hoagwood, K. (2015). Purposeful Sampling for Qualitative Data Collection and Analysis in Mixed Method Implementation. Research Adm. Policy Ment Health. 42: 533.

xxxv. Porter, L., Steers, R., Mowday, R., \& Boulian, P. (1974). Organizational commitment, job satisfaction, and turnover among psychiatric technicians. Journal of Applied Psychology, 59, 603-609.

xxxvi. Rhoades, L., Eisenberger, R., \& Armeli, S. (2001). Affective commitment to the organization: The contribution of perceived organizational support. Journal of Applied Psychology, 86, 825-836.

xxxvii. Robbins, S.P., Judge, T.A., Sanghi, S. (2009). Organizational behaviour (13th ed). New Delhi. Doring Kindersley pvt. Ltd.

xxxviii. Samavi, A. S. (2011). Study of Relationship between Job Satisfaction and Organizational Commitment among HighSchool Managers. Journal of Life Science and Biomedicine, 1(1), 1-3.

xxxix. Silverman, D. (2009). Doing Qualitative Research (3rd ed.). London: Sage Publications Ltd.

xl. Tajfel, H., \& Turner, J. C. (1985). The social identity theory of intergroup behavior. In S. Worchel \& W. G. Austin (Eds.), Psychology of intergroup relations (2nd ed., pp. 7-24). Chicago: Nelson-Hall.

xli. Tashakkori, A., \& Teddlie, C. (2010). Sage Handbook of Mixed Methods in Social \& Behavioural Research (2nd ed.). London: Sage Publications Ltd.

xlii. Thomson, E, R \& Phua, F. T. T (2012). A Brief Index of Affective Job satisfaction. Organisation Management. 37(3): 275-307.

xliii. Tracey, S. J. (2013). Qualitative Research Methods: Collecting Evidence, Crafting Analysis, Communicating Impact. Chichester: Wiley-Blackwell.

xliv. Willig, C. (2013). Introducing Qualitative Research: Research in Psychology (3rd ed.). Maidenhead: Open University Press. 
xlv. Wright, T.A \& Cropanzano, R (2000). Psychological well-being and job satisfaction as Predictors of job performance. Journal of occupational Health Psychology. 5(1) 84-94

xlvi. Yang, J.T. (2010). Antecedents and consequences of job satisfaction in the hotel industry. International Journal of Hospitality Management, 29. 609-619. 